\title{
Review of Fang Fang (2020). Wuhan Diary: Dispatches from a Quarantined City. Trans. M. Berry
}

\section{New York: HarperCollins. 377 pp. ISBN 9780063052659 (E-Book)}

\author{
Petar Jandrić ${ }^{1,2}$ (D) \\ Published online: 23 July 2020 \\ (C) Springer Nature Switzerland AG 2020
}

Keywords Wuhan Diary · Covid-19 · China · Quarantine $\cdot$ Lockdown · Diary

\begin{abstract}
'Wuhan Diary is a knife handed over to foreigners and a bullet shooting at Chinese.' (Davidson 2020)
\end{abstract}

\section{A Bestseller Is Born}

On 25 January 2020, day one of the Lunar New Year and two days after the city of Wuhan entered lockdown, the famous Chinese writer Fang Fang started writing her online diary in her flat not far from the local Huanan Seafood Wholesale Market identified as a possible source of Covid-19 (Maron 2020). This powerful spatio-temporal symbolic, combined with Fang's poignant writing and her 3.8 million strong social media following at the time of publishing her first entry, has soon launched her online Wuhan diary towards huge popularity. In early April, the "“Fang Fang Diary" has had 380m views, 94,000 discussions, and 8,210 original posts' on Chinese social network Weibo (Davidson 2020) and was also mirrored on numerous other places throughout the web. On 24 March, after 60 consecutive days of writing, Fang published her last entry. On 15 May, English translation of Fang's online diary was compiled into a book and published as Wuhan Diary: Dispatches from a Quarantined City (Fang 2020). Following Fang's huge online success, the book has become a best seller in less than a month after its publication, and translations to several other languages are on their way (Siqi 2020).

Petar Jandrić

pjandric@tvz.hr

1 Zagreb University of Applied Sciences, Zagreb, Croatia

2 University of Wolverhampton, Wolverhampton, UK 
When she started writing the diary, Fang did not plan to compile her online entries into a book. This lack of planning clearly shows in text's less-than-perfect transition from short online vignettes to a 377-page volume. Furthermore, the diary has been translated in real time, and such urgency left no time for deep editing. In translator's afterword, Michael Berry describes huge efforts needed to publish the book in English mere 3 weeks after Fang wrote her last entry in Chinese. 'So for 46 days, from February 25 through April 10, 2020, I translated roughly 5,000 words a day (minus a week's break to recover from illness), living amid an unfolding pandemic' (Berry in Fang 2020: 356).

Urgent publication of translation of Wuhan Diary (Fang 2020) to English and other languages is fully justified by book's relevance for the world locked down in anti-pandemic measures. Translating the book from his home in Los Angeles, Berry writes that 'translating a diary written one month in the past, which somehow, simultaneously, offered glimpses into our future' (Berry in Fang 2020: 356). As the pandemic slowly spread around the globe, this insight into Wuhan's reality has become a window into the future for the whole world (see Jandrić 2020). It also opens up a myriad of questions for Western governments and individuals. Why did we not listen to these early warnings? Why did we not care? The western world has largely ignored what happened in China in early days of the Covid-19 pandemic, and only few months later, it has paid a dire price for its arrogance (Jackson 2020). As it becomes clear that Covid-19 is here to stay (Sharping 2020), Wuhan Diary gives a powerful lesson in humility to everyone who thinks that suffering in China, or anywhere else in the world, is not their business. The world has become one, both metaphorically and literally, and Covid-19 teaches citizens of the whole world what it means to live in the Anthropocene.

\section{Fang and Her Critiques}

The world may have become one, but that does not mean we are all the same. Fang's words build a unique rhythm, slow yet powerful, which (for a Western reader) requires some getting used to. Most entries start with innocent weather reports and chatter about Fang's extended family and neighbours. Within these trivial details, Fang masterfully interweaves diverse topics including courage and resilience of everyday people, reports from hospitals and morgues, troubles with obtaining face masks, government's responsibility, censorship, and many others. This slow build-up occasionally culminates in a very open critique of various responses to the Covid-19 pandemic by doctors, government officials, and the Communist Party.

On 6 February, Fang reported about the death of Dr. Li Wenliang. 'He was one of the eight doctors who were penalized for speaking out about the virus early on, and later he himself was infected with the novel coronavirus. Right now everyone in this city is crying for him. And I am heartbroken' (Fang 2020: 61). Until the end of the book, Fang occasionally returns to Dr. Li Wenliang; with each subsequent mention, her grief turns into a deeper and deeper social critique and a call to responsibility:

I realized that this was precisely why we were all so angry about the death of $\mathrm{Li}$ Wenliang. After all, he was the first to speak out, even if all he did was warn his own friends, but by doing that he revealed the truth. But after he spoke out, Dr. Li Wenliang was punished, forced to sign a confession, and later he sacrificed his 
life - no one ever apologized to him before his death. When that is the result of speaking out, moving forward, how can we expect anyone else to speak the truth? (Fang 2020: 64)

In places, her critique almost sounds like a call for action. 'Dr. Ai Fen already sounded the alarm; Dr. Li Wenliang also made some noise; but who is there to carry on their mission? The sound of the whistleblowers has disappeared under the triumphant songs and laughter blaring from those two big media companies.' (Fang 2020: 275-276)

Fang's critique of Dr. Li Wenliang's death is one of many gateways into her deep and poignant critique of the Chinese society. Yet many would say that her critique is not strong enough (e.g. Diterbitkan 2020). Fang is a well-known Chinese writer and a former president of the Hubei Writers' Association, who has lived in the Literary and Arts Federation compound for 30 years, surrounded by other writers and artists recognized and approved by the Chinese government. At the time of writing the diary, Fang was not a superstar, but she was definitely a well-respected member of the Chinese society, and she never tried to hide that. In a moment of self-reflection, Fang writes:

My lifestyle is indeed a bit different from your average person's because I'm a professional writer who has published nearly 100 books. There are a lot of people out there who have read my work and they seem to respect me, especially people here in Wuhan. The fact that I have won a small amount of notoriety for my writings certainly has led some people to go out of their way to help me out; I have to admit that. Sometimes when I go out to eat, the restaurant owner will bring out a special dish, and I even once had a cab driver who refused to accept the cab fare after he recognized me. I am very thankful and moved by all these people's generosity. (Fang 2020: 262)

It is safe to assume that Fang would not be able to maintain such lifestyle, had she been significantly out of the Party line. And yet, Fang is far from a typical regime writer, and Wuhan Dairy is not her first clash with the Chinese establishment. In 2017, her awardwinning novel Soft Burial situated in the age of Mao Zedong's land reform campaign was banned for being too radical (Lam 2017). This places Fang's critique somewhere in the middle: strong enough to stir a lot of water, yet mild enough to keep Fang in good terms with the establishment.

\section{Censorship in the Postdigital Age}

As soon as her diary appeared online, it was strongly censored. In China, Fang's diary has triggered polarized views, 'where some call her a truth-teller but others view her as a liar and traitor' (Siqi 2020). Some examples of this critique include following excerpts from the media. ${ }^{1}$

'Bravo Fang Fang. You're giving Western countries ammunition to target China,' said one post about her on the country's Twitter-like Weibo platform.

\footnotetext{
${ }^{1}$ Please note that I do not read Chinese, so my sources for this review are limited to articles written in English and translations.
} 
'You've shown your treacherous nature', it said.

Another accused Fang of making money off Wuhan's nearly 4000 virus victims, writing: 'How much did you sell the diary for?' (Agence France Presse 2020).

'Wuhan Diary is a knife handed over to foreigners and a bullet shooting at Chinese', said one poster on Weibo.

Another wrote: 'The woman only writes articles in her own small blog, and does not know the overall situation of our country at all. Maybe she does not admit that she is unpatriotic, she thought we were extreme, in fact she was just a stupid old lady' (Davidson 2020).

Yue Zhongyi, a 63-year-old resident of Wuhan, said a lot of the criticism represented nationalist sentiment rather than the views of the city's people.

'I asked all of my neighbours and friends and all of them said they support Fang Fang', he said. 'Her diaries represent our experiences and our feelings'.

The writer's critics misunderstood the notion of patriotism, he said (Lau and Xie 2020).

Fang has received death threats, and her home address has been posted online (Agence France-Presse 2020). Michael Berry, translator of Wuhan Diary, has also 'received thousands of angry emails and death threats for simply translating her writing' (Feng 2020).

In the west, Fang's work has attracted almost unanimously positive reactions. Fang's publishing house, HarperCollins, claims that ' $[\mathrm{t}]$ he stark reality of this devastating situation drives Fang Fang to courageously speak out against social injustice, corruption, abuse, and the systemic political problems which impeded the response to the epidemic' (in Siqi 2020). The Diplomat claims that 'the daily account of the locked down city's millions of inhabitants' untold sufferings during the ongoing health crisis has recast Fang Fang from a well-known literary figure into China's most revered living literary voice of dissent. 'Her fans in China are already proclaiming her to be the conscience of Wuhan’ (Adlakha 2020). Alice Su of LA Times writes:

Hers is a voice of rare authenticity, an antidote to the flood of Chinese propaganda celebrating the country's victory over the coronavirus. She weeps, she shouts, she describes corpses in bags, dragged away and burnt while their loved ones mourn alone. She curses those who concealed the truth and will not apologize even as thousands die. While state media trumpets hero stories and upbeat slogans, Fang Fang speaks plainly of her people's suffering. (Su 2020)

In Wuhan Diary (2020), and also elsewhere, Fang repeatedly insists that her diary is not in any way aimed against the establishment. In an interview for Caixin (2020), she makes a point that 'there's no tension between me and the country, and my book will only help the country' and that her 'diary is by no means about the so-called negative things in China or deliberately peddling misery as misinterpreted by extremists. They take it out of context.' So how do we make sense of all this? Has freedom of speech in China achieved such progress that the Chinese government and Communist Party decided not to censor Fang? Or has Fang's online diary taken them by surprise, so after the diary has become viral, they had no other choice but to play neutral while 
orchestrating attacks from below? Or should we perhaps believe the independent analyst Wu Qiang's hypothesis about the Chinese art of censorship?

Also, despite the backlash she had faced, Fang - who is a former president of the officially affiliated Hubei Writers' Association — was still considered a 'politically trustworthy figure', Wu said, and her work was still available on China's internet.

'Many voices from Wuhan have been silenced. The fact that her work was allowed to survive is the art of censorship: to let out a relatively moderate voice to avoid the embarrassment of a completely blank canvass', he said (Diterbitkan 2020)

For a western person lacking in deep understanding of Chinese culture and society, many domestic implications of Wuhan Diary (Fang 2020) will forever remain a mystery.

\section{Postdigital Dialogue in and for the Twenty-First Century}

Many answers may be left to mystery, yet there is no doubt that that the historical significance of Fang's work reaches well beyond her original thoughts and ideas. The assemblage of Wuhan Diary: Dispatches from a Quarantined City (Fang 2020) and its responses is an almost perfect example of a postdigital dialogue (Jandrić 2017; Jandrić et al. 2019) and an exercise in we-think, we-learn, and we-act (Jandrić 2019; Jandrić and Hayes 2020). As I wrote in my last year's editorial for Postdigital Science and Education, '[a] ny thinking, individual or collective, is derived from and produces learning. Any thinking and learning might have been derived from the actions of someone or something else or might provoke new thinking, learning, or action, by someone or something else' (Jandrić 2019: 278). Furthermore, the trialectic of we-think, we-learn, and we-act is meaningless without our personal feelings (Jandrić and Hayes 2020) and also myth, custom, and religion (McLaren and Jandrić 2020: 256). Sitting at the edge between the online and the offline world, and at the intersections of all these forces, Wuhan Diary: Dispatches from a Quarantined City (Fang 2020) is a truly postdigital book written in a and for our postdigital times.

Many commentators argue that Fang's critique is too strong, and just as many commentators argue that her critique is too weak. To each their own, depending on perspective, both conclusions can be supported by solid arguments. However, there is no doubt that Fang's style of critique is strong enough to attract massive global attention and weak enough to make it into the mainstream. In result, Fang's work has ignited in a hugely important global postdigital dialogue about individual and social responses to the Covid-19 pandemic. Whether we agree with Fang or not, Wuhan Diary: Dispatches from a Quarantined City (Fang 2020) is a true exercise in postdigital critical pedagogy.

\section{References}

Adlakha, H. (2020). Fang Fang: The 'conscience of Wuhan' amid coronavirus quarantine. The Diplomat, 23 March. https://thediplomat.com/2020/03/fang-fang-the-conscience-of-wuhan-amid-coronavirusquarantine/. Accessed 23 June 2020. 
Agence France Presse (2020). Chinese writer faces backlash for 'Wuhan Diary'. France 24, 22 April. https://www.france24.com/en/20200422-chinese-writer-faces-backlash-for-wuhan-diary. Accessed 23 June 2020.

Caixin (2020). Wuhan diary author - There is no tension between me and the country. Caixin Global, 12 April. https://www.caixinglobal.com/2020-04-12/blog-wuhan-diary-author-there-is-no-tension-betweenme-and-the-country-101541748.html. Accessed 23 June 2020.

Davidson, H. (2020). Chinese writer faces online backlash over Wuhan lockdown diary. The Guardian, 10 April. https://www.theguardian.com/world/2020/apr/10/chinese-writer-fang-fang-faces-online-backlashwuhan-lockdown-diary. Accessed 23 June 2020.

Diterbitkan (2020). Coronavirus: Chinese writer hit by nationalist backlash over diary about Wuhan lockdown. https://today.line. $\mathrm{me} / \mathrm{id} / \mathrm{pc} / \mathrm{article} /$ Coronavirus+Chinese+writer+hit+by+nationalist+ backlash+over+diary+about+Wuhan+lockdown-wyOzwa. Accessed 23 June 2020.

Fang, F. (2020). Wuhan diary: Dispatches from a quarantined city. Trans. M. Berry. New York: HarperCollins.

Feng, E. (2020). 'Wuhan Diary' brings account of China's coronavirus outbreak to English speakers. npr, 14 May. https:/www.npr.org/2020/05/14/855122795/wuhan-diary-brings-account-of-chinas-coronavirusoutbreak-to-english-speakers. Accessed 23 June 2020.

Jackson, L. (2020). Weary from the future, Hong Kong. Postdigital Science and Education. https://doi. org/10.1007/s42438-020-00116-5.

Jandrić, P. (2017). Learning in the Age of Digital Reason. Rotterdam: Sense.

Jandrić, P. (2019). We-think, we-learn, we-act: The trialectic of postdigital collective intelligence. Postdigital Science and Education, 1(2), 257-279. https://doi.org/10.1007/s42438-019-00055-w.

Jandrić, P. (2020). Postdigital research in the time of Covid-19. Postdigital Science and Education, 2(2), 233238. https://doi.org/10.1007/s42438-020-00113-8.

Jandrić, P., \& Hayes, S. (2020). Postdigital we-learn. Studies in Philosophy of Education, 39(3), $285-297$. https://doi.org/10.1007/s11217-020-09711-2.

Jandrić, P., Ryberg, T., Knox, J., Lacković, N., Hayes, S., Suoranta, J., Smith, M., Steketee, A., Peters, M. A., McLaren, P., Ford, D. R., Asher, G., McGregor, C., Stewart, G., Williamson, B., \& Gibbons, A. (2019). Postdigital Dialogue. Postdigital Science and Education, 1(1), 163-189. https://doi.org/10.1007/s42438018-0011-x.

Lam, O. (2017). China bans 'soft burial', an award-winning novel about the deadly consequences of land reform. Hong Kong Free Press, 12 June. https://hongkongfp.com/2017/06/12/china-bans-soft-burialaward-winning-novel-deadly-consequences-land-reform/. Accessed 23 June 2020.

Lau, M., \& Xie, E. (2020). Coronavirus: Chinese writer hit by nationalist backlash over diary about Wuhan lockdown. South China Morning Post, 18 April. https://www.scmp.com/news/china/politics/article/3080531 /coronavirus-chinese-writer-hit-nationalist-backlash-over-diary. Accessed 23 June 2020.

Maron, D. F. (2020). 'Wet markets' likely launched the coronavirus. Here's what you need to know. National Geographic, 15 April. https:/www.nationalgeographic.com/animals/2020/04/coronavirus-linked-tochinese-wet-markets/. Accessed 23 June 2020.

McLaren, P., \& Jandrić, P. (2020). Postdigital dialogues on critical pedagogy, liberation theology and information technology. London: Bloomsbury.

Sharping, N. (2020). Could we be living with COVID-19 forever? Discover magazine, 30 March. https://www.discovermagazine.com/health/could-we-be-living-with-covid-19-forever. Accessed 23 June 2020.

Siqi, C. (2020). Chinese vigilant on deifying writer Fang Fang amid publication of Wuhan diary in English. Global Times, 8 April. https://www.globaltimes.cn/content/1185055.shtml. Accessed 23 June 2020.

$\mathrm{Su}, \mathrm{A}$. (2020). Two months into coronavirus lockdown, her online diary is a window into life and death in Wuhan. Los Angeles Times, 21 March. https://www.latimes.com/world-nation/story/2020-03-21/chinawuhan-coronavirus-diary-fang-fang. Accessed 23 June 2020. 